\title{
Appendix
}

Participants' open-ended answers to the questionnaire

(The first 5 questions were closed-ended or required short answers. All answers of Q1, Q2, Q3, Q4 and Q5 were reported in paragraph 4.3. Data collection and analysis).

Q6- The following questions aim to evaluate your teaching experience in distance education during the COVID-19 experience. On 5 March 2020, the Italian Government decided to shut down schools and universities in the country. At first, the closure was due until 15 March, but after the situation got more complicated, Prime Minister Giuseppe Conte decided to extend the closure to uncertain date. In your opinion, did the lack of clear guidelines and transparency from the government and the Ministry of Education have an impact on the application of DE during COVID-19?

Of course, as we didn't know how to manage it

Yes, it did. Even though the general opinion circulating among the teachers was that the closure would be extended up to the end of the school year, it was frustrating to see that there were no clear guidelines. In particular, we didn't know how to reply to some of our students' questions Yes, they did, because not all teachers started DE Yes, it did. At the very beginning we were confused and didn't know exactly what to do.

Of course it did. As a teacher, I lost too much time waiting the government's guidelines about the return to school. During the first 20 days, I worked as if we should have gone back to our classroom in a few weeks, giving homework and online revision exercises. I started with a proper planification only in April.

Yes, it did. I think that we should have been provided with more guidelines, especially for the evaluation of our students 
Yes, It hard a huge impact. We did not know how long DE would last so it was impossible to make a plan about what to do

Yes

Subito dopo l'annuncio della chiusura delle scuole, il Ministero dell'Istruzione ha fatto menzione, in varie dichiarazioni e documenti ufficiali, alla DAD. Tuttavia, il Ministero non ha in alcun modo chiarito con quali modalità e tempistiche si dovesse espletare questo tipo di didattica. Al livello digitale l'Italia registra un forte ritardo rispetto ad altri paesi europei e spesso le realtà regionali sono eterogenee, benché l'Istruzione sia unitaria e nazionale. La mancanza di chiare disposizioni, unitamente ad una mancata regolamentazione normativa, hanno gettato nel caos e nell'improvvisazione varie realtà scolastiche. Di fatto, molti docenti non avevano alcuna formazione e conoscenza di piattaforme, applicazioni per la didattica e software di videoconferenza. In questo vuoto legislativo e in mancanza di chiare istruzioni, molti Dirigenti Scolastici hanno lasciato all'autonomia degli insegnanti la scelta dei mezzi da utilizzare, non potendo prescrivere l'uso di alcuno strumento nello specifico. Inoltre, le scuole non erano in possesso di licenze di utilizzo di software specifici per la DAD e prima che se ne dotassero, i docenti hanno fatto uso di account privati e sofware freeware, con enormi problemi in termini di trattamento dei dati personali e di privacy. La buona volontà e le digital skills dei singoli docenti hanno creato enormi disparità tra discipline, classi e scuole. I docenti cui mancavano queste competenze hanno cercato canali più 'tradizionali' come l'invio di mail e la condivisione di materiale tramite il registro elettronico. Queste modalità ovviamente non hanno permesso un'interazione né un confronto docente-studente, momenti fondamentali nel processo di apprendimento, generando negli studenti una sensazione di sovraccarico cognitivo e nei docenti non preparati alla DAD un senso di frustrazione ed impotenza. 
(Translation: immediately after the announcement of the school closure, the Ministry of Education mentioned DE in several official statements and documents. However, the Ministry has in no way clarified with what methods and timing this type of teaching should be carried out. At the digital level, Italy is lagging other European countries and regional realities are often heterogeneous, although education is unitary and national. The lack of clear instructions and regulations have thrown various scholastic realities into chaos and improvisation. In fact, many teachers had no training and knowledge of platforms, teaching applications and videoconferencing software. In this legal vacuum and absence of clear guidelines, many school principals, not being able to suggest a specific tool, have left teachers autonomous in choosing the tools to use. Furthermore, schools were not in possession of licenses for the DE software usage, and teachers had to use private accounts and freeware software with enormous problems in terms of processing personal data and privacy. The good efforts and digital skills of teachers have created huge disparities among subjects, classes, and schools. Teachers with no digital skills sought more 'traditional' channels such as sending emails and sharing material via the electronic register. Of course, these modalities did not allow teacher - student interactions, which represent crucial moments in the learning process, generating a feeling of cognitive overload in students and a sense of frustration and helplessness in unprepared teachers).

Yes

Yes because we weren't able to carefully plan our work

Yes

It did. There was no clear instruction on how to deliver the DE. 
Q7 - How did the school manage the sudden switch from classroom to online teaching? Did they

provide guidelines, suggest online tools and platforms and support for teachers, students, and families?

My school suggested us to use the platform Google classroom, but I put my efforts and I did my best trying to understand how hangout meet works and how to prepare classes online

Yes and no at the same time. We were asked to get ready and start with the online lessons as soon as we could, but no indication of a specific platform was provided. And we had to guide and support our students in registering to the various platforms: this was time consuming and exhausting.

My school suggested tools and platforms that had already been used My school provided guidelines about online teaching, they also provided free devices for students Who didn't have any. My school also suggested to upload materials on our online register and use Zoom Meeting

The first courses and guidelines for teachers started in May: too late. Me and my colleagues, started trying different platforms, methods, and ideas and sharing them on WhatsApp chats. We did the same with the families. The institution came when we had already arranged the most of it.

Our school let us quite free to choose the most suitable tool and strategies to copy with our educational and personal needs

Yes my School did its best but it was not enough

At first no clear guidelines, then more accurate instructions support for all.

In un primo momento, nel mese di marzo, alcune scuole hanno provveduto a suggerire, tramite circolari interne, una o più opzioni di piattaforme per la $\mathrm{DAD}$, altre hanno assunto fin da subito 
una politica più decisionale che facesse convogliare docenti e studenti verso un'unica piattaforma. Ogni scuola ha operato in autonomia, senza un raccordo. Le scuole più lungimiranti hanno subito creato delle guide operative/tutorial per i docenti, per facilitare nell'uso di questi nuovi mezzi. Tuttavia, per molti docenti non erano sufficienti queste guide operative, necessitando di veri e propri corsi di formazione, che sono stati attivati solo nei mesi di aprile e maggio, in seguito ai finanziamenti arrivati appositamente per questo scopo. Nonostante la buona volontà e i grandi sforzi di molti docenti, tanti studenti e famiglie disagiate e deprivate socioeconomicamente non sono stati 'raggiunti' efficacemente, mancando a questi i supporti e i device per svolgere le attività in modalità a distanza. In alcune realtà scolastiche gli aiuti, in termini di dotazioni di tablet e sim per gli studenti, sono arrivati solo nella parte finale dell'anno, compromettendo gravemente il livello degli apprendimenti.

(Translation: At first, in March, some schools suggested one or more DE platforms, whereas others immediately adopted a more decision-making policy towards a single platform to be used by teachers and students. Each school acted independently. The most far-sighted schools have immediately created operational guides / tutorials for teachers, to facilitate the use of these new means. However, for many teachers these operational guides were not enough, requiring real training courses, which were activated only in the months of April and May, where funding arrived for this purpose. Despite the good efforts of many teachers, students and families from disadvantaged socio-economic background have not been effectively 'reached', for lack of devices and digital competence to perform the tasks online. In some schools, the provision of tablets and sim cards to students arrived only in the final part of the year, seriously compromising the learning).

Yes 
For the first two weeks we were free to experience different tools and platforms, in order to find the most suitable for our way of teaching: for example we started working via email and using two different platforms. After this time of free experimentation, my school made a survey about what we have found to be the best tool/platform and so all teachers should the same platform.

After a couple of weeks of confusion, in my opinion completely understandable due to the unexpected and never experienced before situation, my school gave us ideas and suggestions on how to proceed. There wasn't an official protocol to follow, though. Among a huge range of platforms and tools suggested by the school, teachers were free to choose The school did not provide many guidelines. They only created a professional account to every teacher and students on G Suite but the use of this platform was not compulsory. Also, the DE delivery was not compulsory nor for teachers or for students. Some schools provided laptops the students who did not have one, my school did not provide any laptop.

Q8 - What online tools and platforms are you using in your online teaching and for what activities?

I am using Google classroom and hangout meet. Sometimes I use WhatsApp

WeSchool: where I created the classrooms and published exercises and activities; Zoom: which I used for the online lessons; WhatsApp: to provide students with immediate feedback, to receive their homework when their Internet connection was unstable and they could not complete the activities on WeSchool.

Zoom, Weschool, Microsoft Teams, Microsoft Forms, WhatsApp. They are used for videolessons, tests and exchange of learning materials

Zoom Meetings (videocalls) Online register Screen cast O Matic Google suite for education 


\section{G Suite}

I'm using google classroom to share material and google meet to do lessons.

Edmodo, G Suite for educativo, Zoom, kahoot mainly

Meet, Classroom.

Durante il periodo di DAD, ho utilizzato delle modalità sincrone e asincrone di lezione. Per quanto riguarda le videolezioni, ho optato per Skype in un primo momento. Successivamente, sono passata a Google Meet, quando la scuola si è dotata di licenza per l'uso del pacchetto completo G Suite di Google, creando un profilo istituzionale per ogni docente e studente. Per ciò che concerne le lezioni asincrone, ho condiviso materiale di studio (schemi, testi, immagini, link, file audio), ho creato delle verifiche semi-strutturate tramite Google forms, ho inviato messaggi pubblici e privati, avvisi e compiti tramite la piattaforma Google Classroom, con account privato. Inoltre, ho creato un canale Youtube per condividere con gli studenti delle 'pillole' di teoria di massimo dieci minuti. Gli studenti hanno interagito con me e hanno provveduto alla restituzione dei compiti sempre tramite Google Classroom.

(Translation: during the DE period, I used both synchronous and asynchronous lesson modes. About the video-lessons, I initially opted for Skype. Later, I switched to Google Meet, after the school got the license to use Google's full G Suite package and created an institutional profile for every teacher and student. About the asynchronous lessons, I shared study material (diagrams, texts, images, links, audio files), I created semi-structured tests through Google forms, I sent public and private messages, comments, and assignments through the Google Classroom platform by a private account. In addition, I created a Youtube channel to share theory through up-to-ten-minute video tips with the students. Students interacted with me and returned their homework via Google Classroom). 
$\mathrm{G}$ suite for education $=$ Meet, Classroom

google drive to share explanations, materials and assign exercises; weschool platform to chat with students and comment their homework; zoom for video lessons.

Google meet for lessons Edmodo as e learning platform Socrative and google moduls for tests Screencast for recording the lessons

Edmodo.com to communicate with students. G Suite to deliver online lessons.

Q9 - Do you think you have a good command of digital technologies? To what extent has your digital competence helped you in this situation?

Nowadays I am sure I am a good digital teacher, but I have learnt by myself most of these new technologies

I think I have a good command of digital technologies and this circumstance helped me a lot in this situation.

I have a quite good command of digital technologies and this competence has helped me cope with this unexpected situation

Yes I have a very good command of digital technologies and it definitely helped me to overcome this situation

I had a sufficient knowledge of tools and device, my colleagues, my husband and my students helped me to improve it

I wish I had more experience and competencies

I do have a good command of digital tech. So it's been easy to handle with the new situation Ritengo di avere una buona padronanza delle tecnologie dell'informazione e della 
comunicazione. Ancor prima dell'urgenza della DAD, utilizzavo per alcune delle mie lezioni applicazioni e software per la didattica. Le mie competenze sono state acquisite perlopiù da autodidatta, seguendo numerosi tutorial sul web, webinar e seminari organizzati da vari enti e associazioni, leggendo commenti su gruppi dedicati alle nuove tecnologie nell'insegnamento, spinta da una passione personale per questi mezzi. Grazie a questa formazione di base, sono stata in grado di sopperire fin da subito alle esigenze della DAD e di familiarizzare immediatamente con la piattaforma Google Classroom che non avevo mai utilizzato prima dell'emergenza Covid. (Translation: I think I have a good command of ICT. Even before the urgency to switch to DE, I used teaching applications and software for some of my lessons. I am mostly self-taught, and I attended numerous tutorials on the web, webinars and seminars organised by various organisations and associations, and I read comments on groups dedicated to new technologies in teaching, as I was driven by a personal passion for these means. Thanks to this basic training, I was able to immediately meet the needs of the DE and to become familiar with the Google Classroom platform that I had never used before the Covid emergency).

I have competence but I am not a digital expert. I have moreover had to learn and practice the new ways of teaching

Yes, I think I have a good command of digital technology and this has helped me a lot in this situation because it was easy for me to use different tools, even those I had never heard before.

Didattica a distanza helped me improving my digital skills which were absolutely in need of improvement. A lot still has to be done. Necessity made me improve but there wasn't a real rationale behind it

I think I have a good command of digital technologies and this helped me to be able to use the online platforms, to quickly communicate with students and to share online resources with my 
class.

Q10 - How do you plan and organize an online class and to what extent does it differ from a classroom lesson (timing, tools, methodology, material, contents of the lesson, evaluation)? Are there any differences?

I plan everything before, choosing topics from some digital books. I prepare slides and Google docs to share with students. The lesson lasts about 30 minutes, less than at school, because I can't have students concentrated for much more time

There were some differences: I met my students once a week instead of twice; the evaluation was based on how many times the students [logged] on, if they handed in the activities assigned on time. Materials and contents were transformed and adapted to the digital platform, or were cut off because it was impossible to carry them out (for instance, watching a film in English and set a debate on it)

Basically, the lesson plan is not so different to a traditional classroom lesson plan, but it is essential to be precise on timing. As for evaluation, you cannot be sure $100 \%$ the students are working by themselves

There are differences in time (zoom provides time limited videocalls - 40 minutes), I provide students with power point presentations and then I record my voice through Screencast-O-matic At first I had no preparation so I did more or less the same I have always done in class. I gradually changed and adapt my methods in order to make them fit with the new situation. I started using more videos, online games, webquests and songs

Online classes were shorter than classroom lessons. The main difference was the large use of multimedia tools like videos or online exercises. As for the evaluation, they were mainly based 
on oral interviews

Completely different. Online lessons are shorter, students get distracted very easily.

Online classes include explanations, oral and written tests. They don't differ that much from normal lessons.

Una videolezione richiede una preparazione preventiva che tenga conto dei modificati canali di comunicazione. Soprattutto per quanto riguarda le lingue, è venuto a mancare il linguaggio paraverbale (mimica facciale e gestualità) fondamentale per catturare e mantenere l'attenzione degli studenti. Tenendo conto di questi limiti comunicativi, gli input da trasmettere agli alunni hanno subito una semplificazione e una maggiore schematizzazione. Qualche volta ho sperimentato forme di flipped classroom, lasciando che fossero i ragazzi a scoprire un nuovo argomento, da approfondire e spiegare in maniera più didascalica in una successiva videolezione. I tempi sono stati completamente rivisti e adattati alla situazione. Il monte ore di ciascun docente ha subito delle variazioni e l'unità oraria della disciplina è stata spesso ridotta a lezioni di circa 45-50 minuti, tenendo conto delle difficoltà e del grado di concentrazione degli studenti. I materiali proposti sono stati molto più vari ed eterogenei rispetto a quelli della didattica in presenza. E' stato possibile condividere immagini, link, file audio, testi da varie risorse online. Per quanto riguarda la valutazione, questa è stata globale e olistica, dovendo tener conto dell'impegno profuso, nel complesso, dagli studenti e non centrandosi sui singoli compiti e contenuti restituiti dagli studenti. Le verifiche orali si sono svolte regolarmente, come in presenza, mentre le verifiche scritte hanno posto molti problemi di cheating e di organizzazione. (Translation: a video lesson requires prior preparation which should take into consideration the changed channels of communication. Especially about languages, the paraverbal language facial expressions and gestures- which is essential for catching and maintaining students' 
attention, was lacking. Having considered these communicative limits, the inputs to be transmitted to the pupils were simplified and greatly schematised. Sometimes, I experimented forms of flipped classroom, letting children free to discover, explore and explain a new topic in a following video-lesson. The amount of time has been completely revised and adapted according to the situation. The number of hours for each teacher has been modified and the single lesson reduced to $45 / 50$ minutes, considering the difficulties and the degree of attention of the students. The proposed materials were much more varied and heterogeneous than those of face-to-face teaching. It was possible to share images, links, audio files, texts from various online resources. About the assessment, it was global and holistic, having to consider the commitment made, overall, by the students and not focusing on the individual tasks and contents returned by the students. The oral tests were carried out regularly, while the written tests posed many problems of cheating and organisation).

Yes, a lot. First of all there are always connection problems from my pupils, their devices don't work well (audio, video, or both) or some guys pretend they don't work. I teach as if I were physically in the classroom but I don't have whiteboard support. Interaction is also problematic. If given to written tests, evaluation may not entirely correspond to the pupil's real competence because at home they can have help form a parent/sibling/book/the same PC they are using I plan the same activities of a classroom lesson and I would say that to a certain extent online class is more productive because I don't waste time on telling annoying pupils off. At the same time I can provide extra materials for my pupils avoiding photocopies: I just send them by email or on the platform and pupils can always find them (in this way they can also find my explanations if they have missed them).

Timing is different, it might expand or shrink according to the student reaction to the lesson, 
tools are different: no human connection, no Interactive White Board (IWB), no books, no papers. The content was reduced, the interaction was reduced. Evaluation scale was modified I normally use PowerPoint for my online classes to compensate the lack of a whiteboard. This takes more time than a normal lesson planning as the use of a whiteboard allows you to 'improvise'. Also, the opportunity to 'improvise' in the classroom lesson, allows the teacher to adapt the class according [to] the level of understanding showed by the students.

Q11 - What are the limits and problems you are encountering during an online lesson? Are the same of a classroom lesson?

Of course, most problems are digital ones. For example, students don't have the best tools and the voice is not good and webcams don't work. Sometimes they don't have enough data to be connected for more classes

It is impossible to be sure whether the students are following what you've been explaining or not; some had to have their cameras off for a series of reasons (even technological reasons) and so their presence was nominal only. If something is not clear, students normally ask for further clarifications in a classroom lesson. This doesn't seem to be the norm during an online lesson. Moreover, not all the students have got the same devices and the same available connection: some of them have to share the same computer with their siblings or their parents.

One big giant problem has been connection

You cannot say that students did their homework on their own, there are sometimes problems with their devices, internet, and so on. It is not inclusive for all students. There are some who do not have many possibilities

At first the limits were methodological and technological. Now I improved the methodology, but 
the technical problems due to a weak connection remain.

The main limit is the lack of eye contact with the students, since most of them turn the camera off.

Different. Pack of attention, connection problems, devices problems.

Students choose whether to be online, answer, or even speak, blaming it on the bad connection.

I maggiori problemi riscontrati sono stati la mancanza di supporti digitali o di buone connessioni di rete per gli studenti e le famiglie, soprattutto in contesti particolarmente deprivati socioeconomicamente. Per alcuni studenti, i problemi di connettività portavano ad un malfunzionamento di microfoni e webcam, rendendo disagevole l'interazione durante le videolezioni. Inoltre, alcuni ragazzi hanno mostrato un analfabetismo digitale, dovuto ad un utilizzo delle TIC esclusivamente finalizzato ai social network nella loro pratica quotidiana. Alcuni studenti non avevano alcuna dimestichezza con programmi di scrittura o con funzionalità di base della piattaforma Google Classroom.

(Translation: the biggest problems encountered were the lack of digital devices or a good Internet connection for students and families, especially in disadvantaged socio-economic context. For some students, the connection problems led to misfunction of microphones and webcams, making the interaction difficult during the video-lessons. Moreover, some students showed digital illiteracy since IT tools were used only to surf on social networks. Some students did not have any experience with word processors or Google Classroom and its basic features) I have more problems.

In my opinion the biggest problem is evaluation because it is very hard to be sure that students have done tests by their own, without external help. The other problem is that some pupils often turn off their cameras and microphones and you are not able to understand if they are having 
technical problems or they are just hide themselves to do other things. And finally there is the problem of pupils with disabilities who can't have the support of their teachers.

Students can come up with many excuses when it comes to web cams or homework or assignments you cannot check or validate.

In my opinion the online lessons have a lot of limits and they concern the following fields: difficulty on behaviour management - lower student motivation - lower interaction with the students - interaction between students inexistent - lower level of attention - very slow path of the lesson - difficulty to check students' books - lack of facial expressions as in my school students did not have to show their face on camera (which also allows the teacher to check the students' understanding)

Q12 - If yes, how do you overcome and solve these limits and problems?

We try to help students, giving them best tools (Italian government provided them) and using other apps (WhatsApp) or emails

My school provided those who requested it with a tablet and gigabytes for their connections. I tried to linger on the same topic a bit longer and by creating different types of exercises. The platform https://learningapps.org/ inspired me a lot.

There has been no solution, this problem did not depend on me I check their homework very often and then I do oral tests in order to know if they really studied a specific topic

\section{A lot of efforts!}

Proprio a causa del mancato raggiungimento della totalità degli studenti, in modalità sincrona, si è reso necessario rendere fruibili le lezioni più teoriche tramite dei video registrati e 
successivamente caricati su un canale Youtube, appositamente creato per tale scopo. Spesso ho permesso agli studenti, data la situazione particolare e difficile, di contattarmi in privato, telefonicamente, per guidarli nel corretto utilizzo di questi nuovi mezzi. In rarissimi casi, ho dovuto anche accettare che mi si inviassero dei compiti svolti tramite chat di messaggistica istantanea, come Whatsapp.

(Translation: because of the failure to reach all the students in synchronous mode, it was necessary to make theory classes more accessible through recorded videos which were subsequently uploaded to a Youtube channel, specifically created for this purpose. I have often let students contact me in private by phone, given the exceptional situation, in order to guide them in the correct use of these new means. In rare cases, I had to accept tasks via WhatsApp).

I make the pupils repeat a lot and I try to test them more in oral exams

for the problem of evaluation I give limited time for tests but it is not a definitive solution. For the problems of cameras and microphones I can't do much. For students with disabilities I involve them during the live lesson asking them to do some easy exercises and asking them opinions about a topic.

You trust them or ask colleagues if they have the same problems with them

I think some of these limits may be lightened but not completely solved. The creation of an online platform for the DE could be a plus, but not the problem solution.

Q13 - What are the advantages of an online lesson compared to a classroom-based context? (for example, education accessible for all, inclusive learning...)

Of course in an online lesson, if everything is ok, education is accessible for everyone, but it is not inclusive You can't let students with problems join an online lesson, as they can't and they 
need their families' help

Students who used to forget their homework were immediately spotted.

I think there are two main advantages: - you can mute your students more promptly than in a classroom - pair working and group working are more effective above as far as speaking activities are concerned

Students can feel at their ease at home. Students who normally travel to go to school can feel more relaxed and less stresseddurring an online Lesson

You can improve the learning method of the students, guiding them in a more conscious choice of the information they find on the internet. Moreover, you can use authentic english material more freely.

The advantages of an online lesson are a greater flexibility in terms of timing, the use of multimedia materials that could be more interesting for students

Students could record the lesson and watch it when necessary Availability to access lessons.

I vantaggi di una videolezione sono: 1)la possibilità di utilizzare materiali eterogenei e spesso più accattivanti di quelli presenti nei classici libri di testo in uso nelle varie discipline. 2)le situazioni di disturbo diminuiscono e gli studenti riescono a gestire meglio i turni di parola 3) nelle piattaforme rimane traccia di tutti i compiti svolti e questo permette di redigere report utili ai fini della valutazione finale

(Translation: the advantages of video-lessons are: 1) the chance to use heterogeneous and more engaging material than traditional textbooks. 2) disruptive situations decrease and students can better manage speaking turns. 3) platforms keep track of all tasks performed and this allows to draw up useful reports for the final evaluations. 
For me these are nor advantages

The use of many different tools and materials; no disciplinary problems

Nothing. Online teaching is not inclusive if students don't have the same access to technology.

Plus learning styles are different and only teaching in presence can help students.

Th advantages of an online lesson could be that students do not need to travel to go to school but I personally do not see any other advantages

Q14 - Do you think the sudden COVID-19 emergency may have had a (positive or negative) role in the success or failure of DE practices in Italy?

We have learnt something about technologies, but school has to be done physically. Gestures, rising voice and eyes are the best way to teach

I think that the sudden COVID-19 emergency may have had a positive role in the success of DE practices in Italy because teachers and schools were forced to learn new practices, new methodologies in order to invent and experiment new activities rapidly and efficiently.

The emergency has enabled more and more teachers to use technology for educational purposes, so, to a certain extent it has improved the teaching practices

I Think both of them. Positive: We have become more acquainted to technology Negative: online lessons cannot substitute traditional lessons

We have lost time and had no preparation, so the effect has been negative. However, of the situation continues I am sure we can do better and at the end of the day we will be able to appreciate also some positive aspects in terms of increased learning consciousness and autonomy in building their own knowledge we are

I think that with more technological competences and preparation from the part of teachers, DE 
would have been an extraordinary success

No idea

Success, as many students have shown to be more incline to follow and study. Some students have proved better results in this mode.

Penso che l'emergenza Covid-19 sia stato un forte acceleratore nel processo di ammodernamento e digitalizzazione delle scuole italiane. Tutti i lavoratori della scuola hanno dovuto far fronte a questa nuova sfida, rimettendosi in gioco e sperimentando nuove modalità d'insegnamento che potranno essere utili per il futuro.

(Translation: I think that the Covid-19 emergency has been a strong accelerator in the process of modernisation and digitalisation of the Italian school system. All school staff had to face this new challenge, getting back in the game and experiencing new teaching methods which will be useful in the future).

\section{I can’t express a generalized opinion}

The effect is positive because we have been obliged to use Digital Education tools, but there are also some side effects (too many hours spent in front of a computer screen; no division between working time and personal time; an increase of bureaucratic work because of new reports to be written and new evaluation standards to be discussed and adopted)

Half of this school year was lost. We were not prepared. Teachers are not prepared. We need to be prepared in case a second wave of online teaching happens. We must be trained to make the most of online teaching

I think the COVID-19 emergency may have had a positive impact in the success of DE practices in Italy if the government had spent more time and energy in the definition of clear guidelines and by investing funds in the creation of an excellent online teaching platform and by providing 
every single students and teachers a laptop and a wifi connection. 
Q15 - Will you adopt DE in future teaching practices?

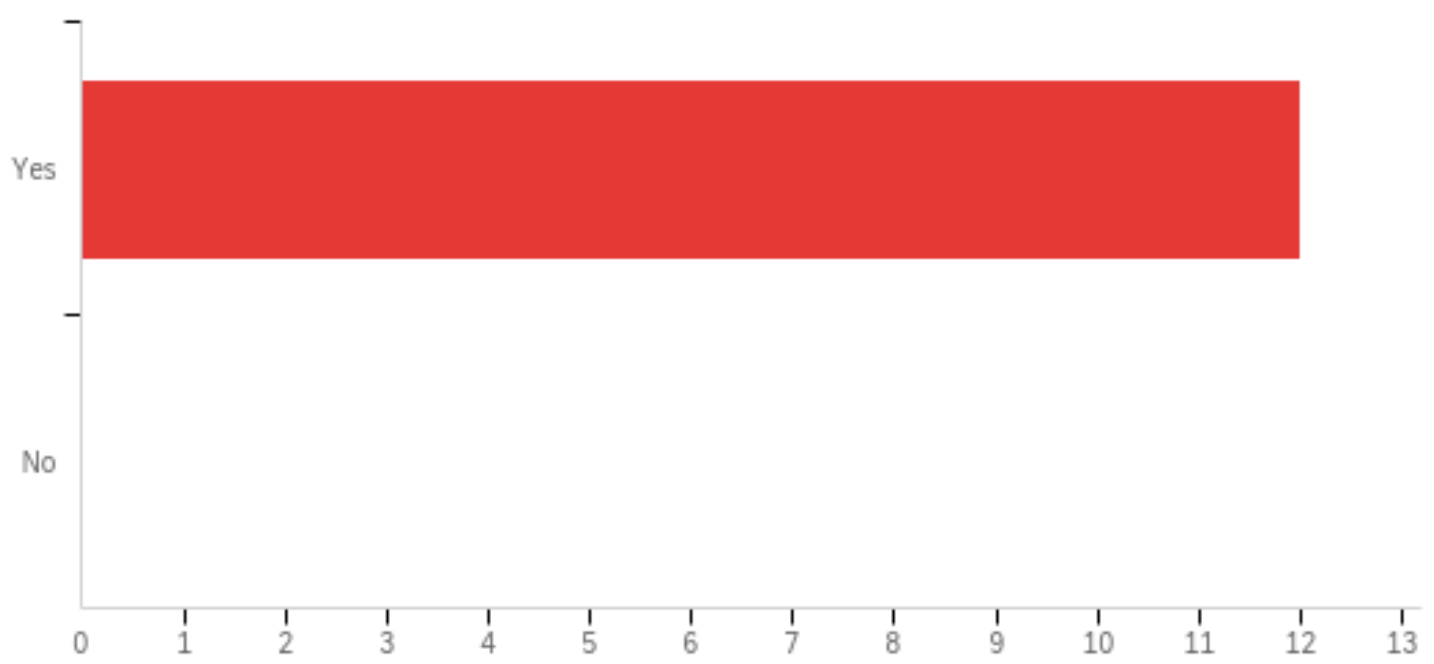

\begin{tabular}{l|l|l|l|l|l|l|l}
$\#$ & Field & Minimum & Maximum & Mean & $\begin{array}{l}\text { Std } \\
\text { Deviation }\end{array}$ & Variance & Count \\
1 & $\begin{array}{l}\text { Will you adopt DE in } \\
\text { future teaching practices? }\end{array}$ & 1.00 & 1.00 & 1.00 & 0.00 & 0.00 & 12
\end{tabular}

\begin{tabular}{l|l|l|l}
$\#$ & Answer & $\%$ & Count \\
\hline 1 & Yes & $100.00 \%$ & 12 \\
\hline 2 & No & $0.00 \%$ & 0 \\
\hline & Total & $100 \%$ & 12
\end{tabular}


Q16 -Justify your answer on the previous questione (Q15):

Sometimes, if I need it

In order to get my students more involved and conscious of their way of learning.

I will adopt it to make my students practice the language in small groups

I think We should take the best part of DE

I am going to use Classroom also during the summer break in order to help then to organize the revision and to start in September with a clearer idea of what they know and what they need to revise. In the future, I am going to organize some meeting with mother tongue speakers

I think I will use some of these practices and tools to share materials with my students

I will make small videos for students who need to see the lesson again and again

Easiness to follow some students

Sicuramente continuerò ad utilizzare la piattaforma Classroom perché ritengo sia una mezzo efficace per condividere materiali e messaggi e perché permette di archiviare il lavoro svolto, creando una cronistoria degli apprendimenti di una classe.

(Translation: I will surely continue to use the Classroom platform because I think it is a effective tool for sharing material and messages and because it allows you to archive the tasks performed, creating a chronicle of the learning of a class).

I will only if I have to

I would continue using some tools in a complementary way to classroom lessons.

I am always in search of improvements

I will adopt a mixed methodology based on classroom teaching with the integration of some DE, but DE will never be my main teaching strategy with secondary school students as I don't 
believe it is as effective as classroom teaching.

Q17 - On a scale from 1 to 5, to what extent do you agree or disagree with the following statements and why? The generation born in this digital and modern age is known as "digital natives" or the "Net-gen" (Prensky, 2001). Digital natives are the generation that spontaneously learns to use the new technologies. However, these 'digital speakers' are used to getting information really fast, they don't like to 'dive' into a text and prefer to 'surf' through hyperlinks. Justify:

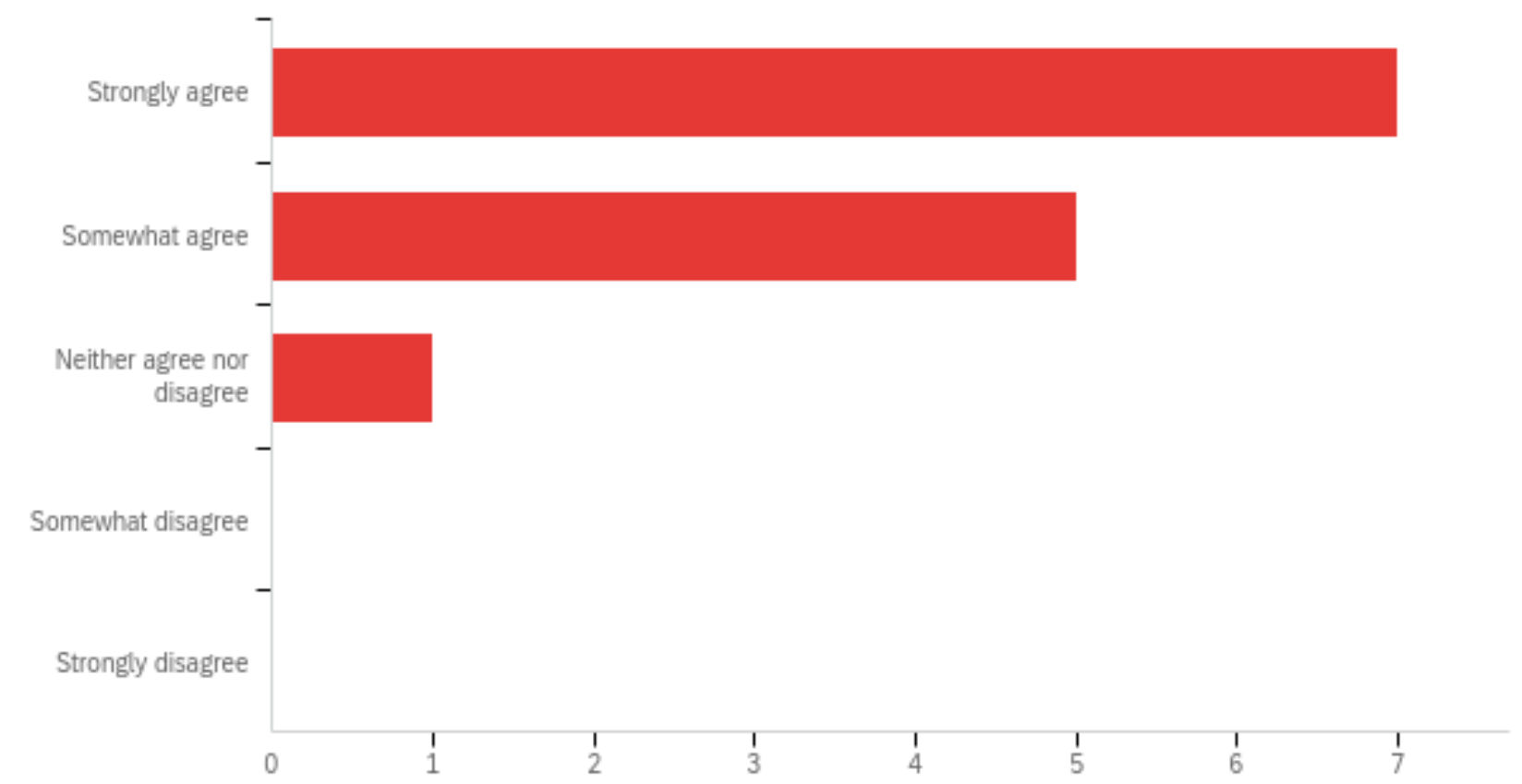

Q18 - Justify your answer on the previous question (Q17):

Some of them are victims of fake news, do not know how to register themselves into a website, the importance of writing their email addresses correctly or of their password I see that students are more superficial about information they normally look for because some how they know that internet will always help them 
I find this generation quite superficial for the easiness to get info or what they want I nativi digitali sono esposti ad un bombardamento di informazioni e di input cui hanno accesso 24h/24 dai propri smartphone. Questo immersione è diventata una pratica che esclude l'approfondimento di qualsivoglia tipo di informazione/stimolo, 'rimandendo in superficie'.

(Translation: digital natives are exposed to a bombardment of information and inputs which they can access 24/7 from their smartphones. This absorption has become a process which excludes the deepening of any kind of information/incentives, 'remaining on the surface').

They prefer to get fast to the conclusion instead of thinking about the process

I see that pupils tend not to read texts carefully and they don't select information.

Technology to them is social media scrolling

I think most of them are used to getting the info really fast

Q19 - Do you think there is more role balance and cooperation, in online learning among teachers, family, and community?

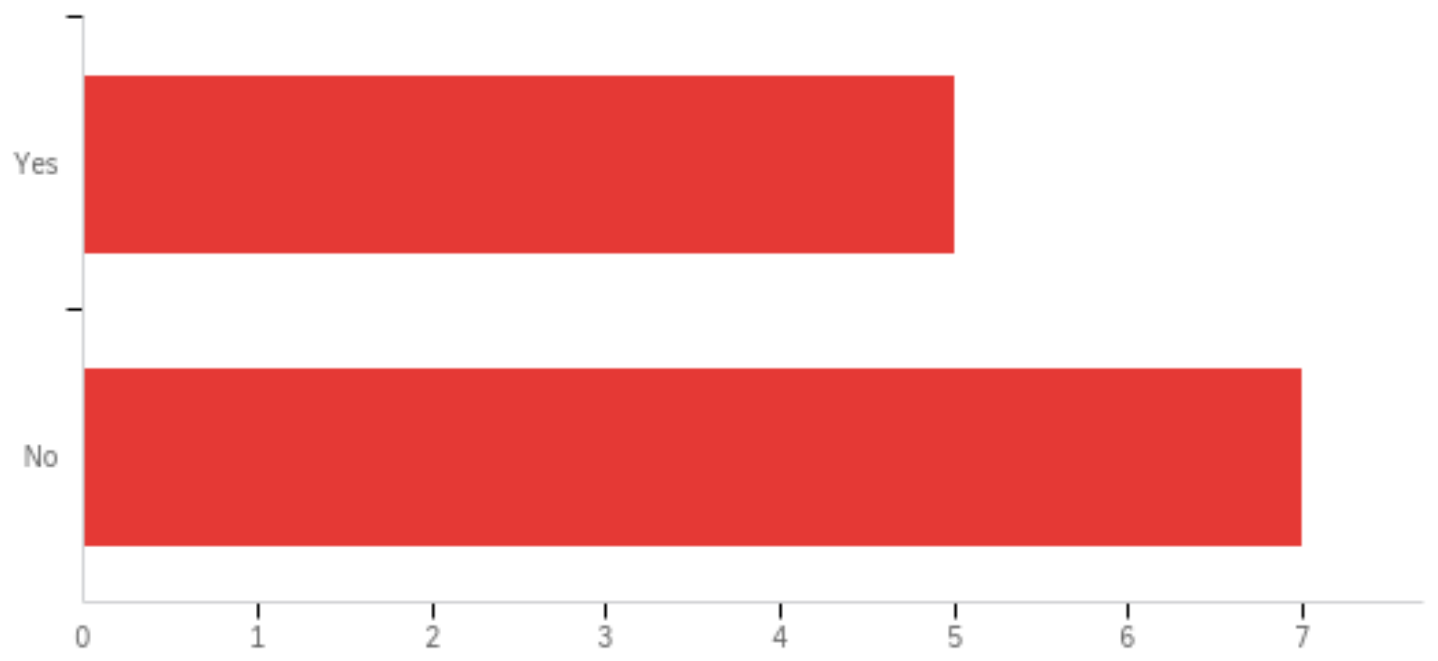




\begin{tabular}{l|l|l|l}
$\#$ & Answer & $\%$ & Count \\
\hline 1 & Yes & $41.67 \%$ & 5 \\
\hline 2 & No & $58.33 \%$ & 7 \\
\hline & Total & $100 \%$ & 12
\end{tabular}

Q20 - Justify your answer on the previous question (Q19):

It is difficult to cooperate with families at distance

It's the same interaction

La DAD ha permesso una maggiore cooperazione e in molti casi c'è stato un vero e proprio peer tutoring, in cui gli alunni più pronti e competenti hanno aiutato i compagni in difficoltà. I docenti hanno veicolato gli input con una maggiore interazione e confronto con gli studenti.

(Translation: DE has allowed a greater collaboration and in many cases there has been a real peer tutoring among students, where the more expert helped their classmates who were struggling).

I think families have suffered the Covid situation. A number of them have not been able to manage it. My colleagues and I have received mails not exactly showing collaboration... I prefer talk to orher teachers in person.

In this situation we have seen that it is quite impossible to have a successful online learning without the cooperation and responsibility of families. Without family support, pupils who were not motivated during 'normal' school activities would be completely lost.

Families most of the time thought we weren't really working. They didn't consider online teaching as a didactic activity

I think families and teachers got a bit more used to online learning during COVID-19 
